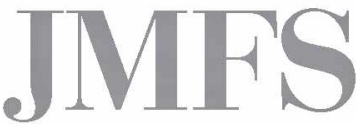

Journal of Management and Financial Sciences
Volume X

•

Issue 29 (September 2017)

pp. $47-72$

Warsaw School of Economics

Collegium of Management and Finance

Jacek Miroński, Rafał Dembowski

Collegium of World Economy

Warsaw School of Economics

\title{
Executive Compensation: Its Structure, Links to Company Performance, Executives' Perception, and International Differences
}

\begin{abstract}
Despite the vast amount of academic research on particular aspects of executive compensation, few studies have undertaken the subject comprehensively, combining the perspective of a firm and a manager in the international context. This study is a review of contemporary executive compensation schemes including its structure and links to company performance. Based on the literature of the topic, the latest market studies and industry expert interviews, this paper determines the role and effectiveness of particular components of compensation packages, taking into consideration executives' perception, motivation, and the existing behavioral biases. Additionally, the study analyses the major differences in executive compensation policies of the listed companies in the US, the UK, Australia, Poland, and Norway. The research conclusions prove that executive compensation maximizing benefits for a firm should not only address the principal-agent problem through properly designed incentives, but also reduce a manager's propensity to excessive risk-taking. Finally, it provides practical recommendations for compensation committees how to effectively design remuneration policies.
\end{abstract}

Keywords: executive compensation, motivation, firm performance, international comparison JEL Codes: M12, M16, M52 


\section{Introduction}

The topic of executive compensation raises a very interesting issue of how sources of individual motivation are translated into a firm's strategy and performance. Most of the academic studies in this matter arise from an interest in the principal-agent problem and its implications for companies ${ }^{1}$.

The key conclusion from the agency theory with regard to managerial pay says: "In order to align the interests of principals and their agents, boards of directors, acting on behalf of shareholders, create incentive contracts which reward executives financially if shareholders' returns increase, but not otherwise."

The agency theory, which has dominated academic thinking about executive compensation, has been a key point of the economic theory of the firm since the 1970s. The theory tends to prioritize the structure of the reward rather than its level as a source of motivation for top managers. Practically, it states that the way how a compensation package is formulated matters more than its total value.

As a result of the common approval for the agency theory, nowadays the most widely-used managerial compensation schemes try to link pay to business performance through bonuses, equity instruments and long-term incentive plans. Moreover, the theory postulates an introduction of external control systems (such as dismissal in case of poor performance, risk of a hostile takeover, affiliations, etc.). An active control of the top management actions performed by company shareholders is the process known as corporate governance.

Management compensation, and the problems of corporate governance related to it, have been widely discussed by the media and political or regulatory institutions for a long time, which was already highlighted by M.C. Jensen and J.L. Zimmerman ${ }^{3}$ (1985). Other current debates about executive pay have been focused on a question if the current level of executive compensation is acceptable to the society and whether remuneration committees do their job properly $y^{4}$.

However, until recently, rather little attention has been paid to executives themselves. One might observe the growing number of behavioral studies looking into the matter from managers' point of view based on psychological research and

1 H. Berkema, P. Geroski, J. Schwalbach, Managerial compensation, strategy and firm performance: An introduction, "International Journal of Industrial Organization", Volume 15, 1997, pp. 413-416.

2 A. Pepper, The Economic Psychology of Incentives: New Design Principles for Executive Pay, Palgrave Macmillan, London 2015.

3 M.C. Jensen, J.L. Zimmerman, Management compensation and the managerial labor market, "Journal of Accounting and Economics" 1985, 7 (1-3), pp. 3-9.

4 PwC, Making Executive Pay Work: The Psychology of Incentives, 2012. 
surveys. A. Pepper ${ }^{5}$ proves that the utility of the standard agency theory in the real life is limited because of its unrealistic assumptions. Those include the claims "that firms are profit seeking, that agents are both rational and rent seeking and that there is no non-pecuniary agent motivation. An agent's utility and performance is assumed to be positively contingent on pecuniary incentives and negatively contingent on effort."

The purpose of this paper is to review contemporary methods of executive compensation including its structure and links to company performance. ${ }^{6}$ The article aims to recognize the role of particular components of managerial compensation packages and determine their effectiveness, taking into consideration executives' perception and existing behavioral biases.

The practical goal of this work is to provide guidelines on the design of an executive pay maximizing benefits for a firm in various contexts (i.a. geography, business culture). This includes identification of the effectiveness criteria for a compensation package and observations with regard to key sources of motivation for executives. Additionally, the study aims to answer the practical question how to properly select and design the determinants of the variable compensation (KPI).

This study brings contribution to the current research by providing further insights with regard to discrepancies observed in the two above-mentioned approaches (a company's and a manager's perspective). Moreover, it brings a new perspective through the usage of the most recent market data from different countries and information obtained through direct interviews from executive search professionals.

\section{Methodology}

This study is mainly based on secondary research. It compiles hitherto academic research with recent market data (available disclosures included in companies' annual reports and market analyses).

Additionally, the paper is supplemented by several singular case studies (based on available disclosures and interviews with executive search experts) illustrating the subject of managerial compensation in different contexts.

The research scope is primarily focused on senior-level executives such as Chief Executive Officer (CEO) and management board members since they have the largest impact on a company's strategy and its execution.

5 A. Pepper, The Economic Psychology... op.cit.

6 Note: This article is not focused at benchmarking compensation levels or examining differences in managerial pay in relation to industry or company size. Moreover, it does not cover the topic of executive compensation as a tool for corporate tax planning. 


\section{Executive Compensation and Company Performance}

It appears to be intuitive that attaching rewards to high performance should motivate managers. However, although merit pay and managerial bonuses have been popular forms of management compensation already for a long time, there have been no rigorous tests of their effectiveness until $1980 \mathrm{~s}^{7}$.

The deeper interest in relation between management compensation and company performance appeared in the studies conducted by K.J. Murphy ${ }^{8}$, A.T. Coughlan and A.M. Schmidt ${ }^{9}$, and G.J. Benston ${ }^{10}$. They provided sound evidence confirming that the level of management compensation and company performance are correlated. However, the direction of causality was not fully explained.

Further research focused on indicating whether the change in company performance is caused by the change in executive remuneration (not vice-versa), treating the pay specifically as an incentive ${ }^{11}$. Later studies, including the article by S.R. Cole $\mathrm{e}^{12}$, examined the issue from the company owner's perspective, emphasizing the impact of compensation schemes on shareholders' return. This approach looks for a reward design which shall maximize managers' performance and reduce principal-agent problems.

Since direct control of senior management efforts and performance very often turns out to be either very costly or infeasible, the agency theory suggests the usage of incentive contracts where remuneration is linked directly to company results ${ }^{13}$.

In practice, a manager's personal wealth is tied to the company's results by various types of bonuses, share ownership, and different forms of long term incentive plans (LTIPs) including stock option plans and other equity-based financial

7 J.L. Pearce, W.B. Stevenson, J.L. Perry, Managerial Compensation Based on Organizational Performance: A Time Series Analysis of the Effects of Merit Pay, "Academy of Management Journal" 1985, 28(2), pp. 261-278.

8 K.J. Murphy, Corporate Performance and Managerial Remuneration: An Empirical Analysis, "Journal of Accounting and Economics" 1985, 7 (1-3), pp. 11-42.

9 A.T. Coughlan, R.M. Schmidt, Executive compensation, management turnover, and firm performance: An empirical investigation, "Journal of Accounting and Economics" 1985, 7 (1-3), pp. 43-66.

${ }^{10}$ G.J. Benston, The Self-Serving Management Hypothesis: Some Evidence, "Journal of Accounting and Economics" 1985, 7 (1-3), pp. 67-84.

11 G.P. Baker, M.C. Jensen, K.J. Murphy, Compensation and Incentives: Practice vs. Theory, "The Journal of Finance" 1988, 43(3), pp. 593-616.

${ }_{12}$ S.R. Cole, The complexity of compensation contracts, "Journal of Financial Economics" 1997, Vol. 43, pp. 79-104.

${ }^{13}$ A. Bruce, R. Skovoroda, The empirical literature on executive pay: Context, the pay-performance issue and future decisions, 2015, p. 10, http://highpaycentre.org/files/academic_literature_review_FINAL. pdf (retrieved on July 4, 2017). 
instruments. However, not all of the above-mentioned instruments are equally effective in creating a beneficial pay-performance link. That is why, the sensitivity of top-management compensation to company performance has been studied in-depth for the last two decades.

Methodologically, K.J. Murphy ${ }^{14}$ proposed the measurement of the link between pay and performance by the following indicators:

- pay-performance sensitivity - showing the absolute incremental increase in a manager's pay associated with a USD 1000 increase in shareholder value;

- pay-performance elasticity - showing the percentage change in a manager's pay associated with a $1 \%$ increase in shareholder value.

Shareholder value can be reflected both by accounting measures (e.g. profit, revenue, return on equity, return on assets) or market indicators (e.g. total shareholder return, Tobin's $Q$ ratio).

Empirical studies conducted in the 1990s were mostly focused on the sensitivity of the cash remuneration (i.e. fixed compensation and annual bonuses). In general, typical estimates for that time suggested that firms increase CEO pay by $1-1.5 \%$ for every $10 \%$ increase in shareholder value, which was a relatively low reward for an exceptional financial performance of the company ${ }^{15}$.

However, cash pay sensitivity, as a measurement of incentive effectiveness, have a limited usability, as they might ignore all the components of the compensation package that are based on the equity valuation. M.C. Jensen and K.J. Murphy ${ }^{16}$ proved that the crucial part of the pay-performance link that affected executive decisions was not caused by annual bonuses but equity-based remuneration instruments (holdings of firms' stocks and stock options).

B.J. Hall and J.B. Liebman ${ }^{17}$ using a sample of almost 500 large American firms, further confirmed the essential role of equity-based components and emphasized the high impact of the option grants on the performance pay. According to their research, the total CEO compensation package (including equity based incentives), on average, would increase by 39 percent if the shareholders' return goes up by 10 percent.

The evolution of research works on executive compensation (from 1980 to 2000) is summarized in Exhibit 1 below. The analysis ends in 2000 as up to this year visible

${ }^{14}$ K.J. Murphy, Executive Compensation, University of Southern California - Marshall School of Business, 1998.

${ }_{15}$ M.J. Conyon, P. Gregg, Pay at the top: a study of the sensitivity of top director remuneration to company specific shock, "National Institute Economic Review" 1994, 149(1), pp. 83-92.

${ }_{16}$ M.C. Jensen, K.J. Murphy, Performance Pay and Top-Management Incentives, "Journal of Political Economy" 1990, 98(2), pp. 225-264.

17 B.J. Hall, J.B. Liebman, Are CEOs Really Paid Like Bureaucrats?, "The Quarterly Journal of Economics" 1998, 113(3), pp. 653-691. 
dominant directions of research can be found. Further literature on the subject is significantly diversified and will be discussed later on.

Exhibit 1. Evolution of academic research findings on executive compensation and company performance $(1980-2000)$

There is a significant correlation between
management compensation and firm performance
-Murphy, 1985; Coughlan \& Schmidt, 1985; Benston, 1985

Managerial compensation works as an incentive for company performance. (Causality link)

- Baker et al., 1988

Majority of the pay-performance link is generated by equity-based instruments.

- Jensen \& Murphy, 1990

Link between managment cash pay (salary \& bonuses) and company performance is low or negligible.

- Conyan \& Gregg, 1994

Sensitivity of executive pay to firm performance rose significantly since 1980 , mainly because of more common usage of stock option grants.

- Hall \& Liebman, 1998

Source: the authors' own analysis based on the articles cited in the chart.

It shows that until 2000 variable components proved to work as an incentive for high-level managers. Moreover, it was found that among these instruments equity-based incentives were more effective than any type of cash bonuses. These research findings are used in the further parts of this paper to verify to what extent remuneration practices adopted on different markets are compliant with the identified patterns.

\section{Fundamentals of Executive Compensation Packages}

Based on the recent market studies conducted in different countries and industry expert interviews, one can firmly state that the most common formulation of an executive compensation package differs significantly from a typical employee's 
compensation scheme. Unlike a typical employee pay, an executive pay is usually contingent to some extent on a company's performance. In general, it is structured by the company's compensation committees with the intent to reward the manager for positive results of the firm and creation of the value for its shareholders ${ }^{18}$.

Whilst some parts of executive compensation, such as salary and annual bonus, are long-established, equity-based remuneration has been developed in the last thirty years. Since its emergence, in many cases it has accounted for an extremely high share of the total executive pay, and had a substantial influence on the level of individual managers' earnings. The adoption of the new type of executive rewards provoked much of the empirical investigation of managerial compensation. What is particularly striking with regard to equity-based pay popularization, is that in the period from 1945 to the mid-1980s there was a relative stability in terms of reward composition $^{19}$.

\section{Executive Compensation Structure}

Current executive compensation packages typically include seven distinct components, which can be found in Exhibit 2. In general, they can be divided into fixed and variable or performance-based parts. The majority of remuneration is paid in cash or financial instruments such as a company's stocks or stock options. However, there are also instruments that reward executives through services, business equipment or retirement plans ${ }^{20}$.

Base salary. The base salary is a fixed component of an executive pay. It is usually paid monthly or once every two weeks, similarly to remuneration of other salaried staff. Most frequently, this part of the pay is subject to personal income tax for the manager and can be deducted as an expense for the company taxation. That is why, in some cases, the level of this compensation component is precisely adjusted for the purpose of tax optimization. For example, in the US, "[...] since 1993, federal tax law limits the amount of cash compensation that companies can deduct as an expense for tax calculations to USD 1 million, unless the compensation is performance-based." 1

${ }^{18}$ EY Norway, Executive and Board Remuneration Report, 2015; EY UK, FTSE 350 Executive and Board Remuneration Report, 2016; PwC Poland, Wynagrodzenia zarzqdów i rad nadzorczych największych spólek gieldowych w 2014 roku, 2015; PwC, Making executive pay work: The psychology of incentives, 2012.

19 A. Bruce, R. Skovoroda, The empirical literature... op.cit.

${ }^{20}$ Center on Executive Compensation, Pay Packages Explained, http://www.execcomp.org/Basics/ Basic/Pay-Packages-Explained (retrieved on 10 April 10, 2016).

${ }^{21}$ Ibidem 
Because of this, inter alia, many large companies try to reduce the base salaries of their executives and provide the rest of the remuneration in the variable, performance-based form.

\section{Exhibit 2. Dominant components of executive compensation packages}

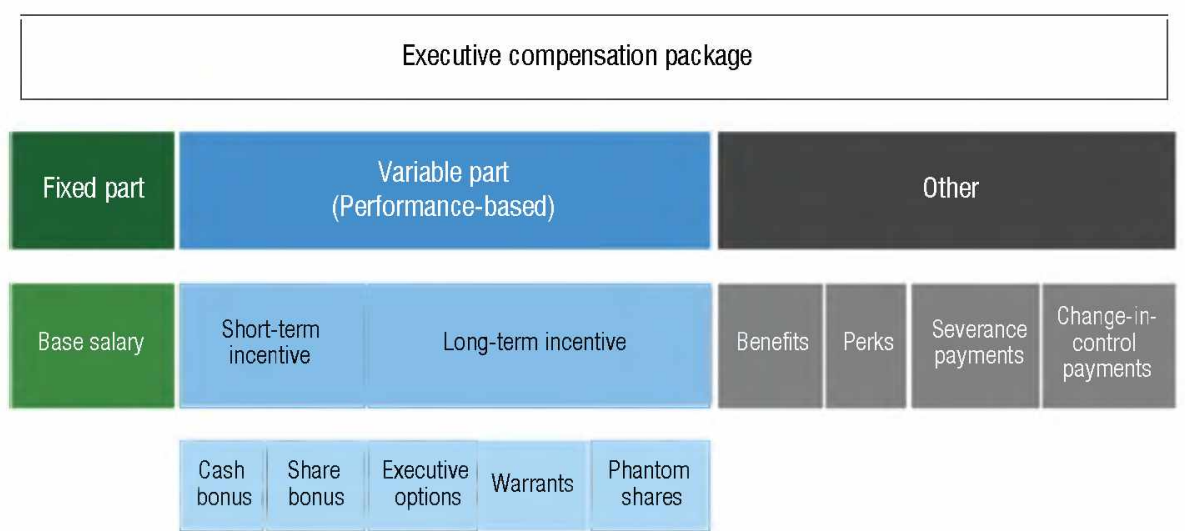

Source: the authors' own analysis based on Center on Executive Compensation, Pay Packages Explained, http://www. execcomp.org/Basics/Basic/Pay-Packages-Explained (retrieved on April 10, 2016), PwC, Making executive pay work: The psychology of incentives, and an expert interview with an executive search specialist for the CEE region.

Short-Term Incentive (STI). This part of a manager's remuneration usually includes a cash bonus (rarely a share bonus) paid annually or quarterly. The key role of this part is to align the executive's priorities with the company's short-term business targets. Typically, the annual bonus is expressed as a percentage of the manager's base salary. The nature of such targets depends heavily on the type of the business, including its size, structure, industry, and multiple other factors.

Long-Term Incentive (LTI). Long-term incentives for executives are usually provided in the form of equity instruments. The purpose of this part of management pay is to encourage them to pursue the company's strategic goal maximizing shareholder value over a long timeframe. This component attracts a lot of attention since it has its ultimate value in binding executives' and shareholders' interests, which has been already highlighted by M.C. Jensen K.J. Murphy ${ }^{22}$. The most prevalent long-term incentive goals are focused on broader measures than short-term ones. These can include total return to shareholders, earnings per share and other return measures, such as return on assets ${ }^{23}$. By definition, the long-term incentive typically depends

\footnotetext{
${ }^{22}$ M.C. Jensen, K.J. Murphy, Performance Pay... op.cit.

${ }^{23}$ Center on Executive Compensation... op.cit.
} 
on the performance within 3-5 year periods. A simple equity tool to achieve this is the issuance of executive options (call options) allowing the recipient to purchase the company's share for a fixed price on a pre-set date in the future.

Employee Benefits. Employee benefit programmes for executives certainly include statutory benefits (familiar to other employees but usually larger in terms of value) such as social, medical and life insurance. Moreover, executives are often eligible to participate in special retirement plans. The money accumulated in these plans might be put at a higher company-specific risk, which should potentially lead to further integration between long-term interests of the executive and the company. However, based on direct interviews with executive search experts, non-wage benefits have rather limited value for executives as an incentive, thus their impact to influence company strategy and performance is negligible.

Perquisites. Executive perquisites (commonly called "perks") include all the extra benefits that help the executive gain recognition within the company and externally. This part also covers special arrangements that need to be made to ensure an efficient working environment for executives. Some executive perks are specifically designed to maximize executive worktime. It may include convenient parking, drivers to and from work, the setup of home communication systems, personal finance services, and even the usage of company aircraft for personal travel. Although executive perks typically constitute a modest component of their total pay and they are not the most appropriate tool to influence strategy, according to executive recruitment experts, in some cultures their impact as an incentive turns out to be higher than expected.

Severance Payments. These contract arrangements provide payments to executives in case of termination of their job. They can play a constructive role in recruitment of new executives or retention of the current managers. Firstly, this compensation component allows mitigating the risks for incoming executives who decided to leave other employment opportunities. Secondly, for longer-serving executives, they can be oriented to protect the stability of their income, therefore maximize retention. Whereas these arrangements are highly appreciated by executives themselves, companies need to be careful with the usage of this tool to ensure that severance agreements do not become incentives for an early leave or taking excessive risks. It can be achieved through provisions such as "non-competition" or "good reason" provisions ${ }^{24}$.

Change-in-Control Payments. Change-in-Control agreements, occasionally referred to as "golden parachutes," protect executives from losing their job due to mergers, acquisitions or a company sale. It is a powerful remuneration component

${ }_{24}^{4}$ J.F. Reda, S. Reifler, M.L. Steven, The Compensation Committee Handbook, John Wiley \& Sons, 2014, p. 338. 
that can encourage executives to look for and accept sale or merger offers when it is aligned with the interest of shareholders. It allows mitigating crucial barriers concerning losing executive positions.

\section{Determinants of Performance-Based Compensation}

Another frequently discussed topic regarding executive compensation is the ratio between fixed and variable pay. An optimal pay mix should provide appropriate incentives to improve business results, and at the same time prevent from excessive risk taking.

The agency theory clearly indicates the advantages of implementing performance-based compensation components for executives. However, an optimal pay mix can be only determined after having a clear understanding of what defines performance and how it should be measured. While it might sound simplistic, without such clarity, it is difficult to identify the kind of performance that should be rewarded. That is why the first stage of creating an effective executive remuneration strategy should be defining appropriate key performance indicators (KPI) that will indicate the level of short-term and long-term rewards.

In practice, possible KPIs can be divided into quantitative and qualitative measures. Quantitative performance measures may include specific targets with regard to a company's revenue, market share, profit, cash flow, number of customers, reduction in costs etc. Qualitative factors are supposed to incentivize the attainment of some special tasks such as implementing a new corporate strategy, development of new products, expanding to a new market, or completion of a critical project ${ }^{25}$.

Short-term (annual) incentives frequently include a three-tier structure: "a threshold level, below which no award is earned, a target level, which is the executive's normal expected performance, and a stretch component, meaning that the company would have to obtain extraordinary results for the maximum incentive to be paid."

Performance vesting KPIs (both qualitative and quantitative) can be also divided by the level of control that an executive has over it. It is widely accepted that KPIs whose realization is more directly contingent on a manager's actions should generate stronger incentive mechanisms. However, companies often use also indirect KPIs such as a global revenue increase to be the factor affecting a regional director's variable salary. It can successfully stimulate cooperation among company executives

25 J.F. Reda, S. Reifler, M.L. Steven, The Compensation... op.cit.

${ }^{26}$ Center on Executive Compensation... op.cit. 
responsible for different areas and integrate their objectives to work for the common interest of all the company's shareholders.

Another criterion to be taken into consideration in the formulation of performance pay is the nature of underlying measures. For example, companies pursuing rapid expansion can attach higher weights to sales growth value while established firms in low-growth industries can make its executives' compensation dependent on market share changes. This feature of the variable pay was studied in more detail by S. Balsam, G.D. Fernando and A. Tripathy ${ }^{27}$. The authors of the article have distinguished two major strategies on the basis of the framework introduced by Michael Porter - i.e. cost leadership and differentiation. They make an assumption that strategy is exogenous and they do not indicate who determines company strategy: shareholders, the board of directors or executives. The key conclusion from their research states that "in determining executive compensation firms consider strategy. In particular firms pursuing a cost leadership strategy place a significantly higher weight on sales and firms which pursue a differentiation strategy place significantly lower weight on ROA."."

Finally, decision makers should take into account the quality of available performance measures. When it is low, the preferred impact of the factor on variable compensation should also be low, and vice versa. Therefore, the mix used for one executive of a specific company cannot be used by a different company based on benchmarking alone ${ }^{29}$.

\section{Managers' Perception of Value}

As mentioned in the introductory part, executive compensation cannot be well explained by a one-sided view from the company's perspective, without analyzing the perception and preferences of executives themselves. It was already proved that executive compensation may affect firm performance and it was shown what compensation tools help mitigate the agency problem. However, it remains not fully explained how the incentive mechanism actually works.

The summary of the crucial forces affecting executive job performance is presented in Exhibit 3. Assuming a given set of capabilities of an executive, one may state that their job performance is directly dependent on their motivation. This can be divided

${ }^{27}$ S. Balsam, G.D. Fernando, A. Tripathy, The impact of firm strategy on performance measures used in executive compensation, "Journal of Business Research" 2011, Vol. 64, pp. 187-193.

${ }^{28}$ Ibidem, p. 192.

${ }^{29}$ EY Norway, Executive... op.cit. 
into intrinsic and extrinsic motivation. The split between those two was introduced to the discussion on employee motivation by B.S. Frey ${ }^{30}$.

Exhibit 3. Executive motivation and job performance cycle

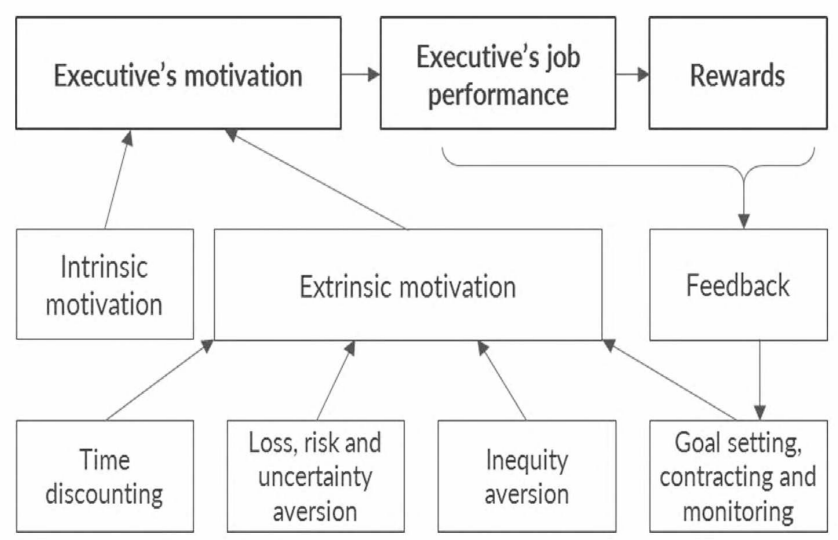

Source: Model based on A. Pepper, The Economic Psychology of Incentives: New Design Principles for Executive Pay, Palgrave Macmillan, London 2015, p. 48.

It is stated that people are intrinsically motivated when they do their work for work's sake. This behavior arises from within the individual and is driven by internal rewards. "Intrinsic motivation theories derive their fundamental ideas from some general assumptions about human needs on lines originally advocated by Abraham Maslow."31 Maslow ordered human needs starting from physiological needs, through safety, intimacy and self-esteem, up to the need for self-actualization. Whereas extrinsic motivation factors (such as money) most often focus on addressing basic needs, the intrinsic ones may potentially touch areas of self-actualization.

The theory of intrinsic motivation is highly applicable to senior executives since they are often responsible for making impactful decisions whose outcomes may be effective motivators. Many of such individuals are largely ambitious, value personal achievements, and enjoy other privileges such as status or power. In these circumstances, their motivation and performance is certainly determined by more than pecuniary incentives alone ${ }^{32}$.

${ }^{30}$ B.S. Frey, On the relationship between intrinsic and extrinsic work motivation, "International Journal of Industrial Organization" 1997, Vol. 15, pp. 427-439.

${ }^{31}$ A. Pepper, The Economic Psychology of Incentives: New Design Principles for Executive Pay, Palgrave Macmillan, London 2015.

${ }^{32} \mathrm{H}$. Berkema, P. Geroski, J. Schwalbach, Managerial compensation, strategy and firm performance: An introduction, "International Journal of Industrial Organization" 1997, Vol. 15, pp. 413-416. 
Extrinsic motivation is activated from outside the person who is concerned. These are typical employee incentives which may be positive (both pecuniary and non-pecuniary) but also negative (threat of financial loss or of dismissal). Extrinsic motivation directly refers to the topic of executive compensation and its structure. The positive agency theory assumes that extrinsic factors of motivation should be perceived by executives in a rational way. However, in reality these assumptions cannot be met and as it was shown by A. Pepper ${ }^{33}$, there are several behavioral biases that affect executives' perception of extrinsic motivation factors (i.e. mainly financial remuneration). The three main psychological effects that have been observed include: time discounting, risk aversion, and inequity aversion.

Additionally, supervision and monetary rewards for executives were found to crowd out intrinsic work motivation (work morale) under identifiable and relevant conditions. As shown by B.S. Frey " work performance decreases if this crowding effect dominates the normally considered disciplining effect of external interventions."

Finally, it is worth realizing that the connection between motivation and job performance is not only a static, single-sided relationship but a dynamic cycle. Usually, a manager's performance is reflected in the principal's feedback for an executive, which has a vital role in the process of goal setting. The process of goal setting and adequate contracting, especially when it includes discussion between the principal and agent about the expected targets, has been found to be positively correlated with the agent's work motivation and performance.

Summing up, the findings of the behavioral agency theory ${ }^{35}$ expand the understanding of the incentive pay far beyond the point explained by the standard positive agency theory. Firstly, it shows that remuneration accounts only for a limited part of an executive's job motivation and performance. Secondly, it states that common behavioral biases may heavily distort the intended links between compensation and performance and they must be seriously considered by compensation committees.

One of the most comprehensive global studies on behavioral aspects of executive compensation that is currently available is a survey carried out in 2012 by PwC in cooperation with LSE. It included over 1100 participants from 43 countries. It provides sound empirical proof for the three key behavioral distortions mentioned above and highlights many interesting differences by country ${ }^{36}$.

\footnotetext{
${ }_{33}$ A. Pepper, The Economic Psychology... op.cit.

${ }^{34}$ B.S. Frey, On the relationship... op.cit.

${ }^{35}$ R.M. Wiseman, L. R. Gomez-Mejia, A Behavioral Agency Theory of Managerial Risk Taking, "The Academy of Management Review" 1998, 23(1), pp. 133-153.

36 PwC, Making Executive... op.cit.
} 


\section{Time Discounting}

In general, company shareholders, corporate governance authorities and regulators commonly assume that deferral in compensation payment is an effective incentive and an instrument properly aligning executives' and long-term shareholders' interests. However, behavioral economists have identified several anomalies in the way that individuals, including executives, account for time.

According to the financial theory, time differences should be adjusted by the conventional discount function. However, the results of the global study conducted by $\mathrm{PwC}^{37}$ show that when there is a deferral of payment, executives across the world apply discount rates that are largely exceeding the discount rates which are applicable according to the financial theory.

Differences between countries presented in Exhibit 4, apart from those caused by a different level of risk-free rate, are driven by overall economic and political stability, as well as cultural differences.

Exhibit 4. Executives' time discount rates applied to deferred compensation by country (2011)

\begin{tabular}{|l|c|c|c|}
\hline \multicolumn{1}{|c|}{ Country } & Time discount rate & Risk-free rate & Number of participants \\
\hline Argentina & $31.2 \%$ & $9.5 \%$ & 14 \\
\hline Australia & $44.4 \%$ & $3.4 \%$ & 31 \\
\hline Brazil & $43.0 \%$ & $6.6 \%$ & 52 \\
\hline China & $30.5 \%$ & $5.4 \%$ & 51 \\
\hline France & $24.4 \%$ & $2.1 \%$ & 35 \\
\hline Germany & $14.6 \%$ & $2.3 \%$ & 31 \\
\hline India & $17.2 \%$ & $8.9 \%$ & 31 \\
\hline Mexico & $69.7 \%$ & $3.4 \%$ & 28 \\
\hline Netherlands & $15.3 \%$ & $2.4 \%$ & 55 \\
\hline Poland & $48.2 \%$ & $4.2 \%$ & 30 \\
\hline Russia & $34.0 \%$ & $8.4 \%$ & 45 \\
\hline South Africa & $52.1 \%$ & $5.0 \%$ & 31 \\
\hline Spain & $18.2 \%$ & $3.2 \%$ & 30 \\
\hline Switzerland & $15.0 \%$ & $0.2 \%$ & 40 \\
\hline United Arab Emirates & $39.4 \%$ & $0.9 \%$ & 75 \\
\hline
\end{tabular}

37 Ibidem. 


\begin{tabular}{|l|c|c|c|}
\hline \multicolumn{1}{|c|}{ Country } & Time discount rate & Risk-free rate & Number of participants \\
\hline United Kingdom & $27.4 \%$ & $4.5 \%$ & 34 \\
\hline United States & $30.8 \%$ & $3.2 \%$ & 123 \\
\hline Other & $49.0 \%$ & $4.9 \%$ & 20 \\
\hline \hline Minimum & $\mathbf{1 4 . 6 \%}$ & $0.2 \%$ & - \\
\hline Maximum & $\mathbf{6 9 . 7 \%}$ & $9.5 \%$ & - \\
\hline Average & $\mathbf{3 3 . 6 \%}$ & $4.4 \%$ & - \\
\hline
\end{tabular}

Source: Survey on 756 executives conducted by PwC, Making Executive Pay Work: The Psychology of Incentives, 2012.

In the case of deferred cash payments made to an executive by a company, the appropriate discount rate should be close to the 'risk-free' interest rate $(0.2-9.5 \%$ per annum depending on the locally observed inflation rate or interest rate paid by government bonds). The study, though, reveals that as far as compensation is concerned, executives tend to use much higher discount factors, typically around $30 \%$ annually.

A clear consequence of this finding is an upward pressure on the overall compensation level. The country data also shows the need of differentiating policies globally.

\section{Risk and Uncertainty Aversion}

The other substantial bias refers to attitudes towards risk and uncertainty with regard to the remuneration scheme. While the majority of executives are expectedly risk averse, there is a certain part of participants (28\%) who are active risk seekers ready to replace their fixed salary for a potentially higher but uncertain bonus (of a lower expected value). There have been identified significant differences in risk profiles between countries, e.g. senior executives in France, China and Mexico demonstrated a greater than average appetite for risk ${ }^{38}$.

This observation confirms that performance-based pay has its cost for the company and as risky bonuses are subjectively discounted by executives, they may demand a premium to compensate for the difference. 


\section{Inequity Aversion}

According to J.S. Adams ${ }^{39}$, employees, which applies to executive employees as well, form their perception of the fair balance between what they give in (including effort, commitment, and skills) and what they receive in return (pecuniary rewards, recognition and opportunities for personal growth) by comparing their own situation with those of other people. Reference points might be internal (peers, subordinates, superiors) or external (people doing the same jobs for different companies). If an executive feels that the relation between inputs and outputs is not fair compared to subjective benchmarks, then the agent will become dissatisfied and because of that less motivated ${ }^{40}$.

The PwC ${ }^{41}$ survey also confirms the theory and shows that for the majority of executives earning more than their peers was more important than earning a higher absolute pay. Nevertheless, there were exceptions - in China and Brazil over 50\% indicated that higher absolute value was more motivating than a relatively higher salary. Similarly, in Central and Eastern Europe as much as $45 \%$ of executives felt that a higher absolute sum was more motivating.

It has two important practical implications. Firstly, although the increased level of disclosure, which is currently supported in many countries, has unquestionable benefits for investors in terms of transparency, it can be value destroying as it provides more opportunities for cross-comparisons. Consequently, executive pay may go up on average. The second thing refers to the compensation structure. On the one hand, complicated, multi-part compensation structures may be an effective tool to prevent executives from direct comparisons. On the other hand, complex setups may also provoke an unjustified feeling of unfairness, so manipulating with different components by compensation committees should be considerate.

\section{Perception of Complexity in Executive Compensation}

Another significant behavioral finding about executive compensation packages states that complexity and ambiguity in executive contracts destroy value. Attempts

39 J. Adams, Inequity in Social Exchange [in:] Advances in Experimental Social Psychology, New York, Academic Press, 1965, pp. 267-299.

${ }^{40}$ A. Pepper, The Economic Psychology... op.cit.

${ }^{41}$ PwC, Making Executive... op.cit. 
of creating managerial contracts perfectly addressing the agency problem may easily end up with extremely complex, performance-based structures including difficult to control and measure KPIs.

Based on the PwC global survey ${ }^{42}$, over $65 \%$ of executives preferred cash plans based on measures that were internal to their organization (e.g. earnings per share) than more ambiguous share plans based on the total shareholder return (including the impact of the market share price). The total shareholder return was mostly disliked in the UK, the Netherlands, Switzerland and Australia - i.e. countries which used this KPI already for the long time and experienced its fallacies in practice. The biggest issue with TSR for executives is a very limited control over its value due to market volatility, which turns out to be frustrating for many of them.

Accordingly, in almost every case, executives favored simpler contracts. The more complex the reward mechanism, the more willing they were to accept the lower but more predictable reward. This finding poses a warning with regard to many long-term incentive plans (LTIPs) that overly complicated systems are frequently counterproductive.

However, decision makers should always consider complexity in relative terms - "if executives deal with the metrics and reporting information that are linked to their awards as a regular part of their job, it will appear simpler to them than it would to someone who only comes across these measures when it comes to assessing their performance." ${ }^{.33}$

\section{Comparative Analysis of Executive Compensation by Country}

There have been rather few studies on the topic of international differences in an executive pay. One of the first extensive research works on the topic, by J.M. Abowd and M.L. Boganno ${ }^{44}$, analysed remuneration costs from the employer's perspective and the value of the received compensation package from the employee's viewpoint in 12 OECD countries, and identified a significant variance in the compensation level and structure. At the same time, it concludes that "the integration of international goods and capital markets provides an economic mechanism driving total compensation costs

\footnotetext{
42 Ibidem.

43 Ibidem.

44 J.M. Abowd, M.L. Boganno, International Differences in Executive and Managerial Compensation [in:] Differences and Changes in Wage Structures. Chicago, University of Chicago Press, 1995, pp. 67-104.
} 
to equality across countries. The integration of world labor markets is required to drive the replacement value of the compensation package to equality across countries." 45

The later study by M.J. Conyon and J. Schwalbach ${ }^{46}$, focused solely on Europe, also confirmed significant differences in executive pay (its level and structure) across countries and analysed four different factors affecting these differences - job position, company size, country specific effects, and different board structures. As a result, they state that country effects on pay were not entirely eradicated by the internationalization of capital and labor markets. The board structure effects remained ambiguous.

In a more up-to-date paper, M. Fernandes, N.A. Ferreira, P. Matos, and K.J. Murphy ${ }^{47}$ made use of the expanded disclosure rules to conduct an international comparative analysis of CEO compensation in 14 countries in 2006 to verify if US CEOs are paid significantly higher than in the rest of the world. They proved that, after controlling for company size, ownership and board characteristics, the premium received by American executives is negligible ( $2 \%$ in 2007). This difference has declined substantially since 2003 (58\%). Cross-country differences in corporate governance with regard to company ownership and board structures proved to be highly significant in international comparisons of the CEO compensation level and its structure ${ }^{48}$.

The majority of the existing comparative analyses were primarily focused on compensation level benchmarking. In order to supplement these findings and provide practical insights to help address the agency problem in a more effective way, we have gathered more detailed data on the executive compensation structure in five countries - the US, the UK, Australia, Poland, and Norway. Data that was used are selected based on publicly available disclosures of the group of the largest publicly listed companies in each country. We are aware that such data may be prone to some methodological weaknesses (such as different average company sizes in the analysed countries). However, in the context of this paper, they demonstrate a valuable view on major structural divergences between the countries.

45 Ibidem.

${ }_{46}$ M.J. Conyon, J. Schwalbach, European Differences in Executive Pay and Corporate Governance. [in:] Corporate Governance, Gabler Verlag, 2000, pp. 97-114.

${ }^{47}$ N. Fernandes, M.A. Ferreira, P. Matos, K.J. Murphy, Are US CEOs paid more? New international evidence, "Review of Financial Studies" 2012, 26(2), pp. 323-367.

48 Ibidem. 


\section{Compensation Package Structure}

As it was shown above, the structure of the compensation package is more important than its value in creating incentives for executives and aligning their interests with shareholders' A precise comparison of the managerial pay structure by country is difficult because of different reporting requirements and subtle differences in definitions of the pay components. However, available market reports provided by international consulting companies allowed extracting the basic split of the executive remuneration to distinguish its fixed part as well as short-term and long-term incentives. Exhibit 5 presents the simplified structure comparison for the analysed countries.

\section{Exhibit 5. Executive compensation structure of publicly listed companies in selected countries (2014)}

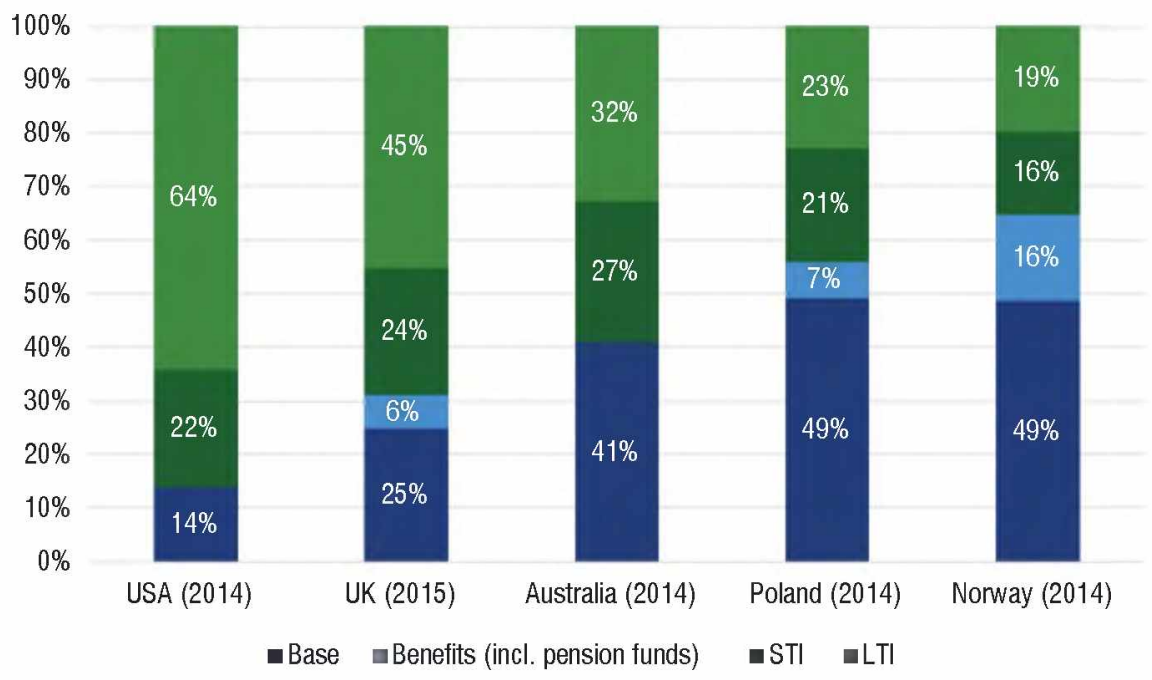

Source: the authors' own analysis based on market reports by Hay Group \& The Wall Street Journal (2015), EY UK (2016), EY Australia (2015), PwC Poland (2015), EY Norway (2015).

As for the share of the variable component, the USA proved to be the market where performance-based compensation is most commonly used and for 300 companies included in the WSJ/Hay Group Index its average share exceeded $85 \%{ }^{49}$. Norway

${ }^{49}$ Hay Group \& The Wall Street Journal The Wall Street Joumal / Hay Group 2014 CEO Compensation Study. www.haygroup.com/us/wsj2014/ (retrieved on July 2, 2017) 
remains on the opposite side of the scale with $35 \%$ average share of the variable component among 57 companies included in OSEBX index ${ }^{50}$. Another characteristic of executive pay in Norway is a higher than elsewhere value of various employee benefits including pension funds arranged by the companies. These features demonstrate a strong preference towards stability for executives within Scandinavian companies, which was also observed in an executive search expert interview.

The latter two European countries in the sample demonstrated a moderate balance between the fixed and variable pay. The UK visibly converges to the US model with an average of almost $70 \%$ of incentive among FTSE 350 companies $^{51}$. The analysed Polish companies from the WIG index, similarly to Norwegian ones, use a rather conservative approach to performance-pay, keeping its share below $45 \%$. It remains in line with the low willingness to take risks by Polish managers ${ }^{52}$.

Australia, which should be theoretically affected by Anglo-American business culture, demonstrates a surprisingly high level of the fixed salary (over $40 \%$ ) in the average executive compensation among the sample of 100 largest listed companies ${ }^{53}$.

Based on these results one can state that a higher share of the fixed salary for executives is preferred in the countries dominated by the German corporate governance model, which implies a more distinct separation of executive and non-executive boards (Poland and Norway).

\section{Construction of Performance-Based Compensation}

The second important dimension of the executive compensation is the construction of the variable compensation instruments and the underlying measures that determine the pay-off. In this field, average executive contracts in the analysed countries demonstrate fewer differences.

Unfortunately, when it comes to short-term incentives (STI), disclosure of the detailed metrics used to determine their value is not required by regulations in most of the countries, which makes it difficult to track and analyse. Based on market statistics found for Norway and Australia (See Exhibit 6), STIs (such as cash bonuses) are usually based on annual or quarterly reported figures. Those can include detailed, company-specific operational measures. In general, depending on a specific executive

${ }^{50}$ EY Norway, Executive... op.cit.

${ }^{51}$ EY UK, FTSE $350 \ldots$ op.cit.

52 PwC Poland, Wynagrodzenia zarzadów... op.cit.; EY Poland, Short-Termism in Business: Causes, Mechanics and Consequences, 2014.

53 EY Australia, EY Pay Perspective 2015 Executive and Board Remuneration Report, 2015. 
role, these are either financial (e.g. revenue, profit or costs) or non-financial factors (e.g. market share, safety measures, people management indicators).

Exhibit 6. KPIs used in STI plans in Australia and Norway (2014)

\begin{tabular}{|l|l|l|l|}
\hline \multicolumn{2}{|c|}{ Australia } & \multicolumn{1}{c|}{ Norway } \\
\hline \multicolumn{1}{|c|}{ Financial } & \multicolumn{1}{c|}{ Non-financial } & \multicolumn{1}{c|}{ Financial } & \multicolumn{1}{c|}{ Non-financial } \\
\hline Profit $(84 \%)$ & Business strategy (68\%) & Profit (31\%) & People measures (67\%) \\
\hline Return (38\%) & People measures (66\%) & Return (24\%) & Health/Safety/Environment (11\%) \\
\hline Costs $(38 \%)$ & Health/Safety/Environment $(52 \%)$ & Others (49\%) & Business strategy (13\%) \\
\hline
\end{tabular}

Note: Percentage in the brackets shows the share of the companies declaring the usage of the KPI. Percentages do not sum up to 100 as companies can use multiple KPIs.

Source: EY Australia (2015), EY Norway (2015)

Apart from KPIs, an interesting observation with regard to executive STI concerns the differences in the level of deferral by country. According to Deloitte Executive Compensation Consulting ${ }^{54}$, most companies in the UK provide short-term bonuses that are at least partly deferred for periods from one year up to three years. Deferral in the USA is less common than in the UK but still exists in some companies. In Australia, deferring part of the bonus into shares is becoming increasingly common. Based on the expert interview working in the Central and Eastern Europe region, the popularity of deferred bonuses in a country depends substantially on the level of political and economic stability. For example, immediate cash bonuses are dominant in Russia, whereas deferred rewards are widely used and accepted in the Czech Republic.

As far as long-term incentives are concerned, the most common KPIs used to determine their value are virtually the same in all the analysed countries ${ }^{55}$. The most prevalent determinants of the long-term incentive plans (See Exhibit 7) focus around total shareholder return (usually relative to comparative companies), earnings per share, and return measures (usually absolute).

The basic overview of the most popular KPIs used to determine short-term and long-term executive incentives shows that despite substantially different weights of these compensation instruments observed by country, their intended role and targets remain consistent between markets. As a result, one can state that the nature of KPIs

54 Deloitte Executive Compensation Consulting, Motivating Top Management through Well-Structured Pay - Key Trends and Issues, 2013.

55 There is no publicly available data on LTI KPIs in Poland but the similar trend was mentioned by executive recruitment specialists in interviews. 
is not subject to cultural or behavioral differences unlike the overall variability of the package or the level of deferral, which should be adjusted to local preferences.

Exhibit 7. KPIs used in LTI plans - Ranking of the most common measures by country (2014)

\begin{tabular}{|l|l|l|l|}
\hline \multicolumn{1}{|c|}{ USA } & \multicolumn{1}{c|}{ UK } & \multicolumn{1}{c|}{ Australia } & \multicolumn{1}{c|}{ Norway } \\
\hline 1. Return measures & 1. TSR (Relative) & 1. TSR (Relative) & 1. EPS \\
\hline 2. TSR & 2. Return measures (Absolute) & 2. EPS (Absolute) & 2. TSR \\
\hline 3. EPS & 3. EPS (Absolute) & 3. Return measures (Absolute) & 3. Other \\
\hline
\end{tabular}

Source: Compensation Advisory Partners (2015), EY UK (2016), EY Australia (2015), EY Norway (2015)

\section{Conclusion and Design Recommendations for Executive Compensation}

\section{Research Conclusion}

This paper investigates various aspects of executive compensation such as package structure, determinants of the incentive pay, and its relation to company performance. The review of the literature on the subject and available market reports lead to the following conclusions:

1. Contemporary executive compensation packages consist of multiple components that play various roles. Whereas some instruments are dedicated to providing the link to company performance (short-term and long-term incentives), the other can be used to reduce a manager's propensity to excessive risk-taking (deferred bonuses) or ensure stability and work effectiveness (e.g. perquisites, benefits).

2. Equity-based executive compensation (such as stock option grants) provides the strongest link to company performance.

3. There are two interrelated types of executives' job motivation - i.e. extrinsic and intrinsic motivation. Extrinsic factors (such as pecuniary compensation) may have a negative impact on intrinsic motivation. Depletion of executive intrinsic motivation generates a significant cost for company shareholders.

4. Behavioral biases such as time discounting, risk aversion, inequity aversion, and complexity aversion decrease the perceived value of executive compensation. The intensity of these effects varies by country. It causes an upward pressure on its objective level, which represents a cost of incentive pay adoption for company shareholders. 
5. Ongoing internationalization of capital and labour markets does not translate into the unification of the compensation structure across countries. On the other hand, the set of KPIs used for determining variable executive compensation reveal a substantial level of convergence across markets.

6. One of the reasons for the variance in the executive compensation level and differences in its structure across countries are differences in the applied corporate governance models.

\section{Design Recommendations}

There is no single executive compensation policy that could satisfy diversified needs of different companies operating on different markets. Reapplication of a successful model from one company to the other may turn out to be totally invalid.

However, based on the findings of this article, the set of guidelines for designing an effective compensation package for senior level executives can be proposed:

1. Apart from measuring the total package value (including equity-based components valuation), compensation committees should consciously decide on the overall compensation sensitivity to company performance. The sensitivity should not be maximized but balanced with other essential objectives such as excessive risk avoidance and stability preferences.

2. Intrinsic motivation must be taken into consideration when analysing the potential impact of executive compensation. Compensation packages should be designed in a way that minimizes the negative impact on the intrinsic motivation and allows leveraging its positive impact - e.g. through implementing non-pecuniary recognition mechanisms.

3. Having in mind the prevalence of different behavioral effects on managers' perception around the globe, companies should try to identify the preferences of individual executives and set the compensation policy accordingly.

4. Compensation committees should carefully set proper KPIs for bonuses that are clearly linked to the field of individual responsibility. E.g. the relative total shareholder return as a KPI for the CEO properly addresses common agency issues.

5. Determinants of the variable compensation (KPIs) for a specific role, once proved to work properly, can be effectively reapplied across countries, whereas the structure of the package should be rather decided case by case. 


\section{Bibliography}

1. Abowd, J.M., Boganno, M.L., International Differences in Executive and Managerial Compensation. [in:] Differences and Changes in Wage Structures. Chicago, University of Chicago Press, 1995, pp. 67-104.

2. Adams, J., Inequity in Social Exchange. [in:] Advances in Experimental Social Psychology. New York, Academic Press, 1965, pp. 267-299.

3. Baker, G.P., Jensen, M.C. \&Murphy, K.J., Compensation and Incentives: Practice vs. Theory. “The Journal of Finance" 1988, 43(3), pp. 593-616.

4. Balsam, S., Fernando, G.D., Tripathy, A., The impact of firm strategy on performance measures used in executive compensation, "Journal of Business Research" 2011, Vol. 64, pp. 187-193.

5. Bebchuk, L.A., Fried, J.M., Executive Compensation as an Agency, "Journal of Economic Perspectives" 2003, 17(3), pp. 71-92.

6. Benston, G.J., The Self-Serving Management Hypothesis: Some Evidence. "Journal of Accounting and Economics" 1985, 7 (1-3), pp. 67-84.

7. Bergstresser, D., Philippon, T., CEO incentives and earnings management, "Journal of Financial Economics" 2006, Vol. 80, pp. 511-529.

8. Berkema, H., Geroski, P., Schwalbach, J., 1997. Managerial compensation, strategy and firm performance: An introduction, "International Journal of Industrial Organization" 1997, Vol. 15, pp. 413-416.

9. Bruce, A., Skovoroda, R., The empirical literature on executive pay: Context, the payperformance issue and future decisions, 2015 p. 10, http://highpaycentre.org/files/ academic_literature_review_FINAL.pdf (retrieved on July 4, 2017).

10. Burns, N., Kedia, S., The impact of performance-based compensation on misreporting, "Journal of Financial Economics" 2006, Vol. 79, pp. 35-67.

11. Center on Executive Compensation, 2016. Pay Packages Explained. http://www. execcomp.org/Basics/Basic/Pay-Packages-Explained (retrieved on April 10, 2016).

12. Cole, S.R., The complexity of compensation contracts, "Journal of Financial Economics" 1997, Vol. 43, pp. 79-104.

13. Conyon, M.J., Gregg, P., Pay at the top: A study of the sensitivity of top director remuneration to company specific shocks, "National Institute Economic Review" 1994, 149(1), pp. 83-92.

14. Conyon, M.J., Schwalbach, J., European differences in executive pay and corporate governance, "Corporate Governance" 2000, pp. 97-114. 
15. Coughlan, A.T., Schmidt, R.M., Executive compensation, management turnover, and firm performance: An empirical investigation, "Journal of Accounting and Economics" 1985, 7 (1-3), pp. 43-66.

16. Deloitte Executive Compensation Consulting, Motivating Top Management through Well-Structured Pay - Key Trends and Issues, 2013.

17. East-West Management Institute, PFS Program - Lectures on Corporate Governance. http://www.emergingmarketsesg.net/esg/wp-content/uploads/2011/01/Three-Modelsof-Corporate-Governance-January-2009.pdf (retrieved on May 31, 2016).

18. EY Australia, EY Pay Perspective 2015 Executive and Board Remuneration Report, 2015.

19. EY Norway, Executive and Board Remuneration Report, 2015.

20. EY Poland, Short-Termism in Business: Causes, Mechanics and Consequences, 2014.

21. EY UK, FTSE 350 Executive and Board Remuneration Report, London, 2016.

22. Fernandes, N., Ferreira, M.A., Matos, P., Murphy, K.J., Are US CEOs paid more? New international evidence, "Review of Financial Studies" 2012, 26(2), pp. 323-367.

23. Frey, B.S., On the relationship between intrinsic and extrinsic work motivation, "International Journal of Industrial Organization" 1997, Vol. 15, pp. 427-439.

24. Hall, B.J., Liebman, J.B., Are CEOs Really Paid Like Bureaucrats?, “The Quarterly Journal of Economics" 1998, 113(3), pp. 653-691.

25. Hay Group \& The Wall Street Journal, The Wall Street Journal / Hay Group 2014 CEO Compensation Study. www.haygroup.com/us/wsj2014/ (retrieved on July 4, 2017).

26. Jensen, M.C., Murphy, K.J., Performance Pay and Top-Management Incentives, "Journal of Political Economy" 1990, 98(2), pp. 225-264.

27. Jensen, M.C., Zimmerman, J.L., Management Compensation and the Managerial Labor Market, "Journal of Accounting and Economics"1985, 7 (1-3), pp. 3-9.

28. Murphy, K.J., Corporate Performance and Managerial Remuneration: An Empirical Analysis, "Journal of Accounting and Economics" 1985, 7 (1-3), pp. 11-42.

29. Murphy, K.J., Executive Compensation, University of Southern California - Marshall School of Business, 1998.

30. Pepper, A., The economic psychology of incentives: New design principles for executive pay. London, Palgrave Macmillan 2015.

31. Pearce, J.L., Stevenson, W.B., Perry J.L., Managerial Compensation Based on Organizational Performance: A Time Series Analysis of the Effects of Merit Pay, "Academy of Management Journal" 1985., 28(2), pp. 261-278.

32. PwC Poland, Wynagrodzenia zarządów i rad nadzorczych największych spótek giełdowych w 2014 roku, Warszawa 2015.

33. PwC, Making Executive Pay Work: The Psychology of Incentives, 2012. 
34. Reda, J.F., Reifler, S., Steven, M.L., The Compensation Committee Handbook, John Wiley \& Sons, 2014.

35. Wiseman R.M., Gomez-Mejia L.R., A Behavioral Agency Theory of Managerial Risk Taking, "The Academy of Management Review" 1998, 23(1), pp. 133-153. 